\title{
Injury Site
}

National Cancer Institute

\section{Source}

National Cancer Institute. Injury Site. NCI Thesaurus. Code C77681.

The anatomic site at which damage or harm was suffered. 